\title{
Optic neuropathy secondary to cat scratch disease: case report
}

\author{
Neuropatia óptica secundária a doença da arranhadura do gato: relato de caso
}

Ricardo Evangelista Marrocos de Aragão ${ }^{1}$, Régia Maria Gondim Ramos ${ }^{1}$, Andreya Ferreira Rodrigues Bezerra ${ }^{1}$, Roberto Briand Cavalcanti Júnior ${ }^{1}$, Thiago Leite Albuquerque ${ }^{1}$

\begin{abstract}
Optic neuropathy due to cat scratch disease is a relatively infrequent occurrence associated with macular star formation and is characterized by sudden painless loss of vision mostly unilateral. Bartonella henselae is well recognized as the etiologic agent in cat scratch disease. Ocular complications of the disease occur in up to $10 \%$ of patients and include neuroretinitis. Ocular bartonelosis is usually self-limited with complete or near-complete recovery of vision in otherwise healthy patients. A case of a boy with neuroretinitis caused by $B$. henselae is reported.
\end{abstract}

Keywords: Optic nerve diseases; Cat-scratch disease; Macula lutea; Macular edema; Papilledema; Retinitis; Case reports

\section{RESUMO}

Neuropatia óptica associada à doença da arranhadura do gato é relativamente infrequente, está associada com formação de estrela macular e caracterizase por perda visual súbita sem dor na maioria das vezes unilateral. Bartonella henselae é o agente etiológico da enfermidade. As complicações oculares da doença ocorrem em mais de 10\% dos casos, entre elas está a neurorretinite. Bartonelose ocular é uma doença autolimitada com completa ou quase completa recuperação da acuidade visual em pacientes imunocompetentes. Relatamos o caso de um adolescente com neuroretinite causada por B. henselae.

Descritores: Doenças do nervo óptico; Doença da arranhadura de gato; Mácula lutea; Edema macular; Papiledema; Retinite; Relatos de casos

\section{INTRODUCTION}

0 ptic neuropathy refers to a clinical disorder characterized by sudden-to-chronic loss of vision in one or both eyes due to optic nerve dysfunction that might be idiopathic, ischemic, primary demyelinating, infectious, or inflammatory in etiology ${ }^{(1)}$. Neuroretinitis is a form of optic neuropathy, characterized by acute painless visual loss in association with optic disc swelling and macular stellated exsudate. It is tipically unilateral and has an excellent prognosis regardless of treatment. Optic neuropathy due cat scratch disease is a relatively infrequent occurrence caused by Bartonella henselae. Other infectious causes include syphilis, Lyme disease, viruses and diffuse unilateral subacute neuroretinitis. Cat scratch disease has been reported in the literature for more than half a century as a syndrome of regional lymphadenopathy and fever. However, it has been only a quarter of a century since Bartonella henselae was identified as the etiologic agent. They are small, fastidious, intracellular Gram-negative bacilli that are aerobic and oxidase-negative ${ }^{(2)}$. Cats are the major reservoir for $B$. henselae, with up to half of domestic cats having antibodies to $B$. henselae. The cat flea is responsible for the major mode of transmission between cats. Once transmitted to humans, following the scratch or bite of a kitten or adult cat, $B$. henselae invades hematopoietic progenitor cells. The response to infection depends on the immune status of the infected host. The typical cat scratch disease is characterized

Study carried out at Ophthalmology Service, Hospital Universitário Walter Cantídeo, Universidade Federal do Ceará - UFC - Fortaleza (CE), Brasil.

${ }^{1}$ Physician, Opthalmology Service, Hospital Universitário Walter Cantídio, Universidade Federal do Ceará - UFC - Fortaleza (CE), Brazil.

Correspondence address: Ricardo E. Marrocos de Aragão. Rua Osvaldo Cruz, 2.335 Fortaleza (CE) - CEP 60125-151 - E-mail: ricardomarrocos@yahoo.com

Recebido para publicação em 11.04.2009

Última versão recebida em 26.09.2009

Aprovação em 06.02.2010 by lymphadenopathy with fever, benign and self-limited, with no other signs or symptoms ${ }^{(3)}$. Other manifestations are less common (hepato-esplenomegaly, granulomatous hepatitis, osteomyelitis, encephalitis, glomerulonephritis, endocardites, and pneumonia). The ocular involvement occurs in $10 \%$ of the cases $^{(4)}$. The most common ocular manifestations is the Parinaud syndrome that consist of fever, regional lymphadenopathy, and follicular conjuntivitis, followed by the neuroretinitis ${ }^{(2)}$.

We describe a case of ocular bartonellosis in one adolescent, with unilateral sudden painless vision loss and neuroretinitis.

\section{CASE REPORT}

A 17-year-old healthy boy suddenly noticed a painless vision loss in his right eye. He denied pain on eye movements and had no systemic or neurological complaints. Measured visual acuity was counting fingers at 1 meter in the right eye (OD) and 20/20 in the left eye (OS). The swinging flashlight test showed a prominent right relative afferent pupillary defect. The fundoscopy in the left eye was unremarkable but in the right eye revealed a diffusely swollen, hyperemic optic disc, serous detachment extending from the disc to the macula, and macular exudates in a stellate pattern (Figure 1 OD). The patient referred scratches on the left arm by a kitten two weeks before his eyesight was affected. Dyschromatopsia was seen in right eye.

Chest $x$-ray, complete blood count with differential was normal. Erythrocyte sedimentation rate was $4 \mathrm{~mm}$. Rheumatoid factor, Venereal Disease Research Laboratory test (VDRL), and fluorescent treponemal antibody absorption test (FTAABS) were negative. Tuberculin skin test was $6 \mathrm{~mm}$. Serologic tests to toxoplasmosis, cytomegalovirosis and HIV 1 and 2 were negative. Cerebrospinal fluid studies revealed normal cell count, normal chemistries, and absent oligoclonal bands. Magnetic resonance images of the head and orbits were normal. 

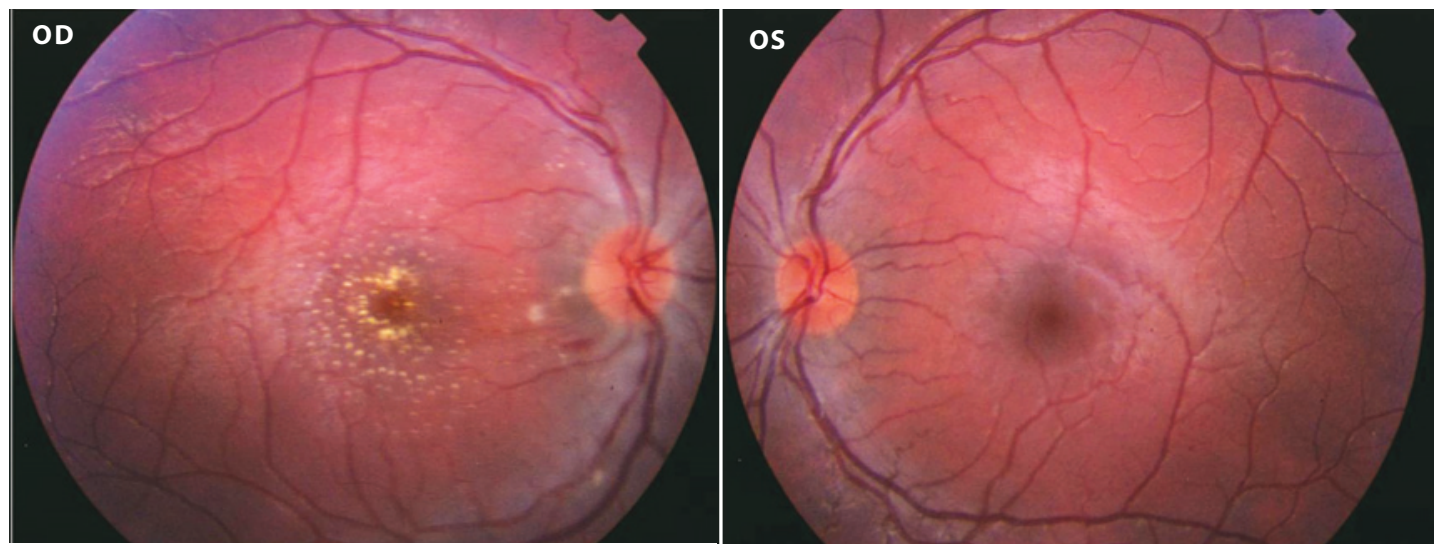

Figure 1. Disc edema and macular star in the OD and normal OS.

The patient started a 3-week course of oral 100 mg Doxycycline once daily.

Bartonella henselae IgG was positive at a titer of 1:1024.

Three weeks after the presentation, visual acuity improved to 20/160 OD. The prominent right relative afferent pupillary defect persisted. The optic disc swelling was markedly reduced and the macula stellate exsudates remained.

Six weeks after the initial presentation, his visual acuity improved to 20/25. The pupillary response was normal. The optic disc swelling diminished and the macular stellate remained in the temporal side.

\section{DISCUSSION}

Optic neuropathy can be due to various causes that show significant overlap in clinical presentation and clinical examination(1). The Optic Neuritis Treatment Trial has shown that intravenous administration of high-dose steroids decreases the risk of progression of optic neuropathy to multiple sclerosis within 2 years of follow-up ${ }^{(5)}$. The diagnosis of the underlying cause of optic neuropathy should be established as soon as possible.

The diagnosis of $B$. henselae infection is clinical, with laboratory evaluation to confirm the initial suspicion ${ }^{(2)}$.

The most common posterior segment ocular complication of $B$. henselae infection is the neuroretinitis ${ }^{(2)}$. Neuroretinitis is characterized by acute visual loss due to optic nerve edema associated with macular exudates in a starlike pattern. The macular star formation may not develop until 1 to 2 weeks after the initial presentation ${ }^{(6)}$. The exact prevalence of neuroretinitis by $B$. henselae infection is unknown ${ }^{(7)}$. On MRI, the optic-globe nerve junction is highly specific for $B$. henselae as cause of optic neuropathy. The macular exudates take months to resolve, and even after resolution, patients may experience abnormal color vision and evoked potentials, subnormal contrast sensitivity, residual disc pallor, afferent pupillary defects, retinal pigment changes, and mildly decreased visual acuity ${ }^{(2,8)}$. There are reports of ocular Bartonella disease with optic disc edema and retinal detachment without the classic macular stellate exudative ${ }^{(9)}$. Other posterior segment presentations of B. henselae infection include panuveites, central retinal artery and vein occlusion, neovascular glaucoma, macular hole, choroiditis, retinal microgranulomas, serous macular detachment, multifocal chorioretinitis, and papillary vasoproliferative changes ${ }^{(3-4,10)}$.

Whether immunocompetent individuals with ocular cat scratch disease need treatment is debatable since the natural progression is for complete recovery within a few months. However, systemic antibiotics do seem to shorten the disease duration and speed visual recovery. Alternatives to azythromycin include rifampicin, ciprofloxaxin, gentamicin, and trimethoprim-sulfamethoxazole, in order of increased effectiveness ${ }^{(2)}$. Although the prognosis is on the whole good there may be residual loss of visual acuity, disc pallor, afferent pupillary defects and retinal pigmentary changes.

Early signs that help to distinguish $B$. henselae-associated papillitis and/or neuroretinitis from other forms of anterior optic neuropathy are therefore important for both diagnosis and therapy ${ }^{(9,11)}$.

\section{REFERENCES}

1. Schmalfuss IM, Dean CW, Sistrom C, Bhatti MT. Optic neuropathy secondary to cat scratch disease: distinguishing MR imaging features from other types of optic neuropathies. AJNR Am J Neuroradiol. 2005;26(6):1310-6. Comment in: AJNR Am J Neuroradiol. 2005;26(6):1303-4.

2. Florin TA, Zaoutis TE, Zaoutis LB. Beyond cat scratch disease: widening spectrum of Bartonella henselaeinfection. Pediatrics. 2008;121(5):e1413-25.

3. Gray VA, Michels KS, Lauer KA, Samples JR. Bartonella henselae infection associated with neuroretinitis, central retinal artery and vein occlusion, neovascular glaucoma, and severe vision loss. Am J Ophthalmol. 2004;137(1):187-9.

4. Asensio-Sánchez VM, Rodríguez-Delgado B, García-Herrero E, Cabo-Vaquera V, García-Loygorri C. [Serous macular detachment as an atypical sign in cat scratch disease]. Arch Soc Esp Oftalmol. 2006;81(12):717-9. Spanish.

5. Lana-Peixoto MA. Neuro-Oftalmologia. Sistema sensorial: parte I - Revisão $1997-$ 1999. Arq Bras Oftalmol. 2002;65(1):118-36.

6. Bhatti MT, Asif R, Bhatti LB. Macular star in neuroretinitis. Arch Neurol. 2001;58(6): $1008-9$.

7. Donnio A, Buestel C, Ventura E, Merle H. Neurorétinite à Bartonella henselae: maladie des griffes du chat. J Fr Ophtalmol. 2004;27(3):285-90.

8. Chai Y, Yamamoto S, Hirayama A, Yotsukura J, Yamazaki H. Pattern visual evoked potentials in eyes with disc swelling due cat scratch disease-associated neuroretinitis. Doc Ophthalmol. 2005;110(2-3):271-5.

9. Wade NK, Levi L, Jones MR, Bhisitkul R, Fine L, Cunningham ET Jr. Optic disk edema associated with peripapillary serous retina detachment: an early sign of systemic Bartonella henselae infection. Am J Ophthalmol. 2000;130(3):327-34.

10. Albini TA, Lakhanpal RR, Foroozan R, Holz ER. Macular hole in cat scratch disease. Am J Ophthalmol. 2005;140(1):149-51.

11. Reed JB, Scales DK, Wong MT, Lattuada CP Jr, Dolan MJ, Schwab IR. Bartonella henselae neuroretinitis in cat scracht disease. Diagnosis, management, and sequelae. Ophthalmology. 1998;105(3):459-66. 